\title{
PENGOLAHAN CABAI SEGAR MENJADI PRODUK OLAHAN " TEPUNG CABAI "
}

\author{
${ }^{1}$ Yukiman Armadi, ${ }^{2}$ Neti Kesumawati, ${ }^{3}$ Rita Hayati \\ ${ }^{1,2,3)}$ Universitas Muhammadiyah Bengkulu \\ Corresponding author : Yukiman001@gmail.com
}

\begin{tabular}{|c|c|}
\hline $\begin{array}{l}\text { Informasi Artikel } \\
\text { Terima: 05/04/2021 } \\
\text { Revisi : 05/04/2021 } \\
\text { Disetujui : 30/04/2021 }\end{array}$ & $\begin{array}{l}\text { ABSTRAK } \\
\text { Kecamatan Curup Utara yang terletak di Propinsi Bengkulu } \\
\text { merupakan dataran tinggi dengan kondisi tanah yang subur dan } \\
\text { cocok untuk usaha budidaya tanaman. Banyak hasil-hasil } \\
\text { pertanian yang berasal dari daerah ini, salah satunya adalah } \\
\text { cabai merah keriting yang mempunyai tingkat kepedasan yang } \\
\text { tinggi. Biasanya cabai ini menjadi inceran wisatawan yang }\end{array}$ \\
\hline $\begin{array}{l}\text { Kata Kunci: } \\
\text { Holtikultura, Umur } \\
\text { Simpan, Tepung Cabai }\end{array}$ & $\begin{array}{l}\text { datang ke daerah ini untuk dijadikan buah tangan. Kondisi ini } \\
\text { merupakan peluang bisnis yang tidak dapat diabaikan karena } \\
\text { menguntungkan secara ekonomi sehingga dapat meningkatkan } \\
\text { perekonomian para petani cabai. Pada tahu } 2016 \text { luas tanam di } \\
\text { Kecamatan Curup Utara } 34 \text { ha dengan produksi mencapai } 289 \\
\text { ton. Hasil yang berlimpah ini di satu sisi sangat membahagiakan } \\
\text { para petani tetapi di sisi lain membuat miris hati petani karena } \\
\text { banyaknya cabai yang tidak laku terjual dan membusuk. Apalagi } \\
\text { hasil produksi cabai mereka kalah bersaing dengan cabai-cabai } \\
\text { yang masuk dari daerah lain, seperti Lampung dan Padang. } \\
\text { Berdasarkan hasil pembicaraan awal dengan anggota kelompok } \\
\text { wanita tani Matahari, mereka menghendaki agar para penyuluh } \\
\text { member informasi berupa ilmu pengetahuan dan ketrampilan } \\
\text { tentang pengolahan cabai segar menjadi tepung cabai. Hal } \\
\text { mendasari permintaan mereka adalah produk ini akan dapat } \\
\text { dijual ke pasaran pada saat harga melonjak tinggi sehingga dapat } \\
\text { meraup keuntungan yang besar; pembuatannya sangat mudah; } \\
\text { serta bahan bahan bakunya (cabai) sangat melimpah di } \\
\text { Kecamatan Curup Utara. Bentuk kegiatan yang akan dilakukan } \\
\text { diantaranya berupa; pendidikan dan penyuluhan tentang } \\
\text { pengolahan pascapanen; pelatihan dalam pembuatan tepung } \\
\text { cabai. Kegiatan pengabdian yang dilakukan diharapkan akan } \\
\text { meningkatkan wawasan anggota kelompok wanita tani Matahari } \\
\text { dalam pengolahan cabai segar menjadi tepung cabai dan } \\
\text { meminimalisir kerugian di tingkat petani cabai akibat banyaknya } \\
\text { cabai yang rusak/busuk. Dari aspek produksi akan dihasilkan } \\
\text { produk tepung cabai. }\end{array}$ \\
\hline
\end{tabular}

\section{PENDAHULUAN}

Kecamatan Curup Utara

Kabupaten Rejang Lebong terdapat di kaki bukit Basah dengan luas daerah $395 \mathrm{Ha}$ atau hampir 0,26\% dari luasan kabupaten secara keseluruhan. Ibu 
kecamatan berjarak $3 \mathrm{~km}$ dari ibu kabupaten dan $88 \mathrm{~km}$ dari ibu kota Propinsi Bengkulu. Konturnya berbukit, suhu rata-rata $23-320 \mathrm{C}$ dengan tingkat kelembaban $40-80 \%$. Kondisi geografi yang terletak di kaki bukit Basah inilah yang menyebabkan tanah di sekitarnya sangat subur sekali sehingga cocok untuk budidaya pertanian. Hasil-hasil pertanian banyak berasal dari daerah ini, salah satunya adalah cabai merah keriting yang menjadi unggulan daerah ini, dimana luas tanam pada tahun 2014 lalu 34 ha, dengan produksi 271,5 ton (BPS, 2020).

Cabai merah keriting berukuran agak kecil, rasanya sangat pedas, banyak mengandung gizi, diantaranya kalori, protein, lemak, kabohidarat, kalsium, vitamin A, B1 dan vitamin C (Nurfalach, 2010). Sedangkan menurut (Hudzaifah, 2014), vitamin yang terkandung dalam cabai dan berguna bagi tubuh, salah satunya adalah vitamin C dan Provitamin A ( $\beta$-karoten).

Menurut (Moekasan \& Prabaningrum, 2011), cabai merah merupakan salah satu komoditas tanaman sayuran yang banyak dibudidayakan karena daya adaptasinya yang luas dan mempunyai nilai ekonomi tinggi, Pemanfaatan komoditas sayuran tersebut sebagaian besar adalah untuk keperluan rumahtangga yang dikonsumsi dalam bentuk segar, kering atau olahan. Sedangkan (Warnita \& Aisman, 2017), cabai merah sebagian besar digunakan untuk konsumsi rumah tangga dan sebagiannya diperdagangkan dalam bentuk cabai merah segar. Penjualan dalam bentuk segar sering menimbulkan permasalahan kerugian secara ekonomi, terutama pada saat panen berlimpah dan cabai tidak laku terjual. Cabai ini akan mengalami pembusukan sehingga tidak layak untuk diperjual-belikan. Kondisi inilah yang akhirnya berdampak pada menurunnya pendapatan petani cabai. Keadaan seperti ini dialami oleh petani cabai di Desa Tasik Malaya, terutama anggota kelompok wanita tani Matahari yang pada umumnya merupakan petani cabai.

Perilaku petani tersebut di atas yang menjual dalam cabe segar harus diarahkan pada penjualan cabe dalam bentuk produk olahan yang berniali jual tinggi. Kebiasasaan menjual cabai merah keriting untuk kebutuhan rumah tangga dan keperluan industri, diantaranya industri bumbu masakan, industri makanan dan industri obat- 
obatan atau jamu harus dirubah.. Semua ini membuka peluang bisnis yang sangat menguntungkan bagi petani dan pedagang cabai sehingga memiliki potensi untuk meningkatkan perekonomian mereka. (Dewanti et al., 2010), menyatakan cabai (Capsicum annum L.) merupakan salah satu komoditas sayuran yang banyak dibudidayakan oleh petani di Indonesia karena memiliki harga jual yang tinggi. Apalagi kalau cabai segar ini diolah menjadi produk olahan yang bernilai tambah tinggi akan lebih memungkinkan para petani mendapatkan keuntungan yang besar.

Selain itu, penjualan dalam bentuk produk olahan dapat meminimalisir kerugian akibat pembusukan cabai yang merupakan sampah organik yang berpotensi menghasilkan air lindi sebagai polutan pencemar lingkungan. (Widarti \& Muryani, 2018), tumpukan sampah organik mudah terurai dan menghasilkan air lindi yang berbau busuk dan berpotensi mencemari tanah, air tanah dan sungai sekitarnya.

Sehubungan perilaku petani yang menjual cabe segar diketemukan beberapa permasalahan, seperti :
a). Komoditas
cabai
segar

merupakan komoditas yang mempunyai masa simpan pendek sehinggga sering mengalami pembusukan.

b) Komoditas cabai segar asal Desa Tasik Malaya Kecamatan Curup Utara belum termanfaatkan secara optimal sehingga petani mengalami kerugian

c) Pengetahuan dan ketrampilan petani dalam pengolahan pascapanen cabai segar menjadi produk olahan tepung cabai masih minim

Berdasarkan permasalahan di atas, maka perlu dilakukan penyuluhan pengolahan cabai segar segar menjadi produk olahan tepung cabai kepada anggota kelompok wanita tani Matahari yang diharapkan bisa menjadi informan kunci dalam penyebaran teknologi tersebut kepada masyarakat sekitarnya serta mencapai tujuan pengabdiaan masyarakat, antara lain :
a) Memperkenalkan teknologi sederhana kepada anggota kelompok wanita tani Matahari Desa Tasik Malaya tentang pengolahan tepung cabai

b). Memanfaatkan sumberdaya alam 
yang berlimpah, berupa komoditi cabai yang belum termanfaatkan secara optimal

c) Meningkatkan pengetahuan dan ketrampilan anggota kelompok wanita tani Matahari Desa Tasik Malaya dalam pengolahan tepung cabai

\section{METODELOGI PENELITIAN}

Sifat cabai merah keriting dalam bentuk segar memiliki umur simpan yang pendek akibat kerusakan mikrobiologi/fisiologi dan kerusakan fisiologis (Kesumawati \& Hayati, 2016). Sementara cabai merah dari Kecamatan Curup Utara kalah bersaing dengan cabai dari luar daerah kota Curup (Lampung, Jambi dan beberapa kota di Sumatera Selatan) yang kualitasnya lebih baik dan lebih murah dan kadar airnya lebih rendah. Hal ini berakibat pada penimbunan hasil panen, terutama pada saat harga anjlok dipasaran dan menimbulkan kerugian di tingkat petani. Maka dirasa tepat bila cabai merah keriting tersebut bisa diolah menjadi tepung cabai (bubuk cabai). agar memiliki nilai tambah. Menurut Agar solusi lebih mudah diterima dan diserap oleh anggota kelompok wanita tani Matahari maka teknologi yang dipilih haruslah sederhana, murah, mudah dilaksanakan dan berbasis pada potensi lokal.

Agar mempermudah pelaksanaan kegiatan maka sangat perlu dibagi dalam beberapa tahap, yaitu :

a) Pendidikan dan Penyuluhan

Untuk menambah wawasan anggota kelompok tani dilakukan melalui pendidikan dan penyuluhan tentang arti pentingnya mengolah cabai segar menjadi produk olahan tepung cabai

b) Pelatihan

Agar anggota kelompok tani dapat lebih memahami cara mengolah cabai segar menjadi tepung cabai yang benar maka mereka akan diberi pelatihan

Pembuatan tepung cabai sangat sederhana, baik dari bahan dan alat yang digunakan maupun cara mengolahnya. Bahan-bahan yang digunakan mudah didapat di pasaran dengan harga yang tidak terlalu mahal. Sedangkan peralatan yang digunakan bisa memanfaatkan peralatan di dapur, seperti terlihat tabel 1. 
Tabel 1. Bahan dan perlatan pembuatan tepung cabai

\begin{tabular}{|c|c|c|c|}
\hline No. & Bahan & & Peralatan \\
\hline 1. & Cabai & & Baskom \\
\hline 2. & $\begin{array}{l}\text { Natrium } \\
\text { metasulfit } \\
\%\end{array}$ & 0,2 & Blender \\
\hline 3. & Air & & Saringan \\
\hline 4 & & & Ayakan \\
\hline 5. & & & 5 buah pisau \\
\hline 6. & & & Nampan \\
\hline
\end{tabular}

Sumber : (Saputro \& Susanto, 2016)

Di samping bahan dan alat yang sangat sederhana, cara kerja pembuatan tepung cukup sederhana juga. Adapun prosedur kerja pembuatan tepung cabai, sebagai berikut :

1. Pilihlah cabe yang sudah masak dan bersihkan

2. Hilangkan tangkai cabe yang sudah dibersihkan dan lakukan pembelahan

3. Celupkan belahan cabe dalam air panas yang susunya mendekati titik didih $\left(90^{\circ}\right) \quad$ (blanching) selama 60 detik

4. Agar warna cabe tetap bewarna merah, masukkan Natrium metasulfit $0,2 \%$ kedalam air celupan di atas

5. Angkat cabe dari perendaman dan tiriskan
6. Tata cabe yang sudah diangkat dari rendaman di atas nyiru, lalu dijemur di panas matahari sampai benar-benar kering atau setelah kadar air mencapai $12 \%$.

7. Giling cabe yang sudah kering dengan menggunakan hingga menjadi serbuk cabe

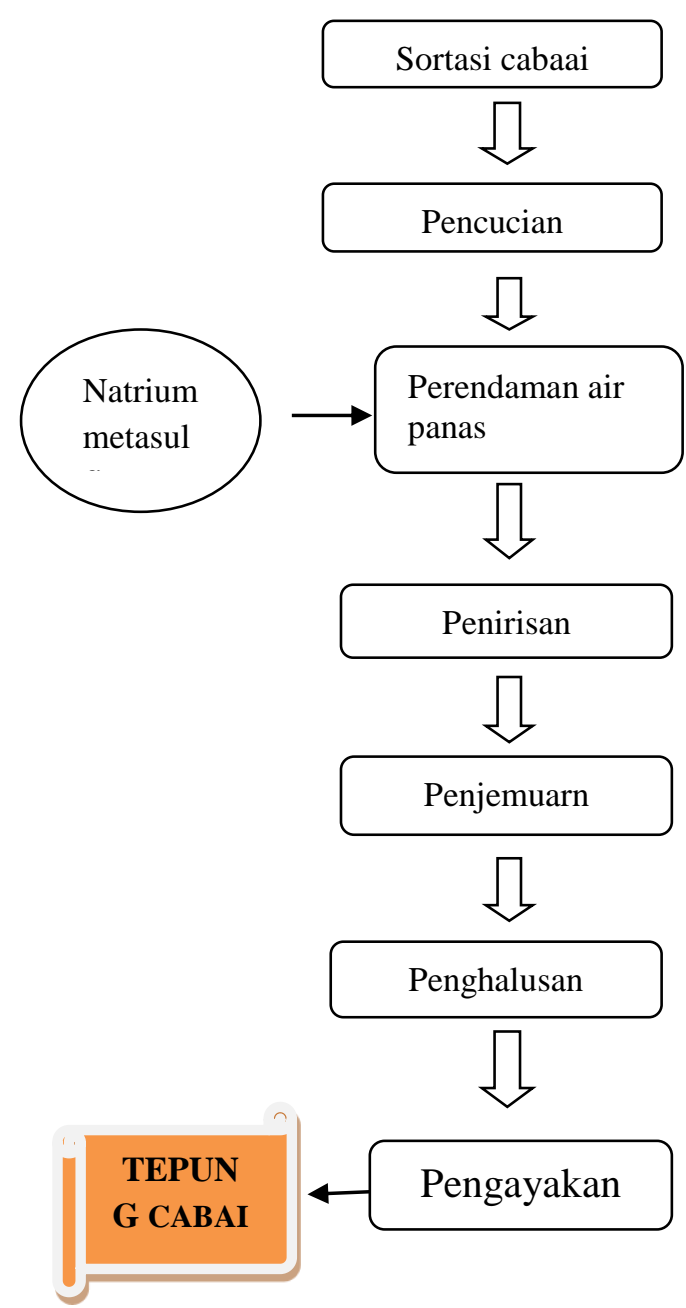

Gambar 1. Diagram alir pembuatan tepung cabai 


\section{HASIL DAN PEMBAHASAN}

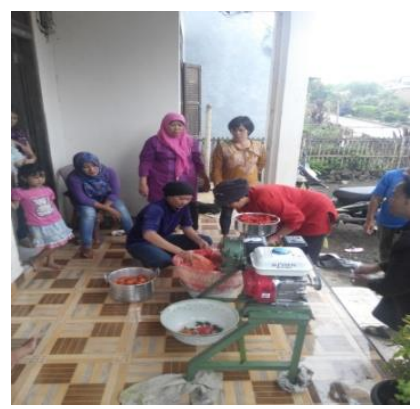

Gambar 2. Pelatihan pembuatantepung cabai

Pembuatan tepunga cabai merah di Desa Tasik Malaya belum pernah dilaksanakan oleh masyarakat petani Desa Tasik Malaya, khususnya anggota kelompaok wanita tani Matahari. Mereka pada umumnya menjual cabai mereka dalam bentuk segar yang menimbulkan reziko pembusukan pada saat panen. Menurut (Bahar et al., 2020), penanganan hasil cabai merah yang banyak dilakukan ditingkat petani hanya sebatas penanganan segar, berupa pembersihan, sortasi, penirisan dan pengepakan sederhan, bahkan tidak melakukan tahapan itu sama sekali. Penangan cabai seperti itu akan berdampak penumpukan hasil panen apabila tidal laku terjual. Oleh karena itu, perlu diperkenalkan produk olahan yang lain, seperti tepung cabai. Pengenalan bertujuan untuk memberikan pengetahuan tentang pengolahan cabai segar menjadi tepung cabai.

Metode yang digunakan dengan dua metode pendekatan hanya dalam bentuk penyuluhan dan pelatihan. Pada pendekatan secara penyuluhan, para peserta diberi ilmu pengetahuan tentang arti pentingnya mengolah cabai segar menjadi produk olahan, terutama tepung cabai serta cara pembuatan tepung cabai secara teori. Sedangkan pada pendekatan secara pelatihan, para peserta diajak langsung membuat tepung cabai dengan didampingi para penyuluh. Dari kedua pendekatan yang dilaksanakan telah menambah wawasan para anggota KWT karena sebelumnya mereka hanya mengenal cara mengolah cabai segar menjadi cabai kering saja.

Dari minat mereka yang cukup besar dalam mengikuti penyuluhan/ pelatihan, alangkah sebaiknya ditindaklanjuti kegiatan ini dengan pembuatan produk - produk lannya, seperti abon cabai, manisan cabai, cabai kering, dlll

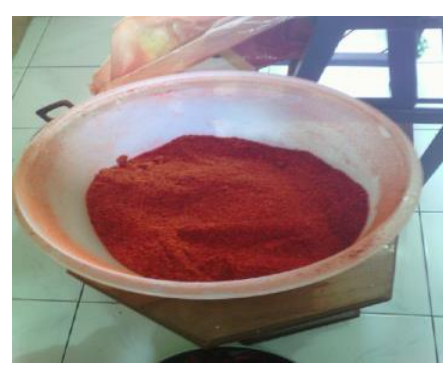

Gambar 3. Tepung cabai

Diakhir kegiatan diharapkan anggota kelompok wanita tani paham dan memiliki kemampuan untuk memperpanjang masa simpan cabai 
merah, mampu mengurangi resiko kegagalan dalam usaha cabai merah, terutama pada saat terjadinya penimbunan hasil panen, mampu memanfaatkan teknologi pengolahan cabai merah menjadi saos cabai

Selain itu, pada akhir kegiatan pengabdiaan masyarakat diharapkan dapat memenuhi target, sebagai berikut :

a) Pemberdayaan kelompok wanita tani Matahari melalui penguasaan teknologi pengolahan cabai merah menjadi tepung cabai

b) Produk olahan tepung cabai

\section{KESIMPULAN DAN SARAN}

\section{Kesimpulan}

a) Kegiatan peyuluhan/pelatihan berhasil memberdayakan anggota KWT

Matahari

b) Kegiatan pengabdian masyarakt direspon yang tinggi dan antusias oleh anggota KWT Matahari terhadap semua kegiatan yang telah dirancang oleh tim penyuluh

c). Pelaksanaan kegiatan memberikan dampak positif bagi anggota kelompok wanita dalam hal peningkatan pengetahuan dan ketrampilan pengolahan cabai egar menjadi tepung cabai

\section{Saran}

a. Perlu penyuluhan dan pelatihan .pembuatan produk olahan cabai segar yang

Bervariasi

b. Bagi anggota kelompok wanita teratai bisa berfungsi sebagai informan kunci

dalam penyebaran pengetahuan dan ketrampilan tentang pengolahan cabai menjadi produk olahan saos cabai

\section{DAFTAR PUSTAKA}

Bahar, Y. H., Achidayat, Promosiana, A., Suharto, Y. B., \& Ichniarsyah, A. N. (2020). Kaji Terap Teknologi Penanganan Pascapanen Cabai Rawit Merah (Capsicum frutescens L.) Melalui Proses Pengempaan Dan Diversifikasi Pengolahan Aneka Cabai.

BPS, 2020. (2020). Rejang lebong dalam angka. 2020.

Dewanti, T., Rukmin, W. D., Nurcholis, M., \& Maligan, J. M. (2010). Aneka produk olahan tomat dan cabe. 7 November 2010.

Hudzaifah. (2014). PENGARUH PROSES PEMASAKAN PADA CABAI BESAR (CAPSICUM ANUNUM L) TERHADAP KADAR VITAMIN C DAN PROVITAMIN A ( $\beta$-KAROTEN). UNIVERSITAS MUHAMMADIYAH 
SURAKARTA.

Kesumawati, N., \& Hayati, R. (2016).

DIVERSIFIKASI PRODUK

OLAHAN CABAI MERAH KERITING SEBAGAI ALTERNATIF PENANGANAN PASCA PANEN CABAI MERAH DI KECAMATAN CURUP UTARA KABUPATEN REJANG LEBONG. Dharma Raflesia Unib Tahun XIV, 167-176.

Moekasan, T. K., \& Prabaningrum, L. (2011). Budidaya Cabai Merah di Bawah Naungan untuk Menekan Serangan Hama dan Penyakit.

Nurfalach, D. R. (2010). Budidaya Tanaman Cabai Merah (Capsicum annum L.) Di UPTD Perbibitan Tanaman Hortikultura Desa Pakopen Kecamatan Bandungan Kabupaten Semarang. Universitas Sebelas Maret.

Saputro, M. A. P., \& Susanto, W. H. (2016). PEMBUATAN BUBUK CABAI RAWIT ( KAJIAN KONSENTRASI KALSIUM PROPIONAT DAN LAMA WAKTU PEREBUSAN TERHADAP KUALITAS PRODUK ). Pangan Dan Agroindustri, 4(1), 62-71.

Warnita, \& Aisman. (2017). PEMBERDAYAAN MASYARAKAT MELALUI BUDIDAYA TANAMAN CABAI MERAH DALAM POT. Ilmiah Pengabdian Kepada Masyarakat, 1(2), 41-50.

Widarti, I. W., \& Muryani, E. (2018). KAJIAN KUALITAS AIR LINDI TERHADAP KUALITAS AIR TANAH DI SEKITAR TPA (TEMPAT PEMROSESAN AKHIR) SAMPAH JETIS, DESA
PAKEM, KECAMATAN GEBANG, PURWOREJO, JAWA TENGAH. Tanah Dan Air (Soil and Water Journal), 15(Juni), 1-9. 